Efectos sobre el rendimiento académico en estudiantes de secundaria según el uso de las TIC

\title{
Effects on academic performance in secondary students according to the use of ICT
}

Luis Miguel Benítez Díaz. Universidad Nacional de Educación a Distancia. lbendia@gmail.com

M. a Luisa Sevillano García. Universidad Nacional de Educación a Distancia. mlsevillano@edu.uned.es

Esteban Vázquez Cano. Universidad Nacional de Educación a Distancia. evazquez@edu.uned.es

\section{RESUMEN.}

El interés principal del presente estudio fue evaluar el grado de asociación que el uso de las TIC pudo tener en el rendimiento escolar en la materia de matemáticas y en un área geográfica limitada. Los datos fueron obtenidos gracias al Programa de Evaluación Internacional de Estudiantes (PISA). Participaron 1376 estudiantes de las Islas Canarias. Para obtener la mejor aproximación posible al fenómeno se utilizó un método de investigación mixto, donde se utilizó un análisis de modelo lineal jerárquico (HLM) para valorar las características de los estudiantes y los centros escolares. Los resultados reflejaron cambios positivos en el rendimiento escolar influyendo en ellos el uso eficaz de las TIC. Se demostró que el aprendizaje puede potenciarse gracias a las TIC, a menos que su uso no sea el adecuado.

\section{PALABRAS CLAVE.}

TIC en la educación, alfabetización informacional, aprendizaje eficaz, análisis multinivel.

\section{ABSTRACT.}

The main interest of this study was to evaluate the degree of association that the use of ICT could have to school performance in mathematics, within a limited geographical area. The data was obtained thanks to the International Student Assessment Program (PISA). 1376 students from the Canary Islands participated. To obtain the best possible approximation to the phenomenon, a mixed research method was used, in which a linear hierarchical model (HLM) analysis was used to assess the characteristics of students and schools. The results reflected positive changes in school performance influenced by the effective use of ICT. It was shown that learning can be enhanced thanks to ICT, unless its use is not appropriate.

\section{KEYWORDS.}

ICT in education, information literacy, effective learning, multilevel analysis.

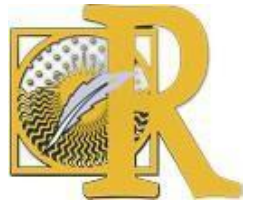




\section{Introduction.}

At present, countries' economic growth relies on the degree of importance they attach to their technological development. The countries that benefit most from the use of technology will obtain a greater increase in their competitiveness and wellbeing (Baller, Dutta, \& Lanvin, 2016). E-learning is of increasing interest to society and educational institutions, as knowledge is increasingly important, and E-learning supports the concept of permanent learning (Alenezi, 2018; Fombona \& Vázquez-Cano, 2017; Sevillano \& Vázquez-Cano, 2015; Vázquez-Cano, 2014).

This increases the demand for diverse educational media and formats. Different education programs around the world cater to this increase in demand and offer new forms of education that are often compatible with information and communication technology [ICT] (Sulcic \& Lesjak, 2009; Moore \& Kearsley, 2012; Simonson, 2012). Technological advances, on the other hand, have revolutionised teaching and learning processes (Fry, 2001; Aristovnik, 2012, 2014), for example, there are researchers who point out that the rapid expiration of knowledge and training, the need for fast delivery of information, and the need for more cost-effective teaching methods have transformed teaching and learning practices. In the future, as Baris has suggested in a recent investigation, E-learning will become completely necessary in combined learning format educational processes (blended learning), in which traditional learning will play only a supporting role (Baris, 2015). The information age has also influenced public administration, and many researchers believe that digital communication and distance learning (as part of continuous training) are basic skills that public administrators should take into account (Liu \& Yen, 2014; Umek, Aristovnik, Tomazevic, \& Kerzic, 2015).

A persistent concern within current education is the objective of achieving better results and reducing the number of dropouts, and it is recognised that the fulfilment of these objectives may require a change in the teaching methods used (López-Pérez, Pérez-López, \& Rodríguez-Ariza, 2011).

Learning and ICT can mutually benefit each other. Several attempts have been made to implement models of ICT integration within education, for example there are authors who at the end of the 1990s suggested an active learning perspective made possible by Technology Enabled Active Learning [TEAL] (Belcher, 2001; Breslow, 2010; Cinganotto, Panzavolta, Garista, Guasti, \& Dourmashkin, 2016), in which it is suggested that technology should be used to support meaningful learning using computer systems and that, instead of integrating technology, the strategy should be based on technology-enabled learning, so that ICT is seen as a way of enabling participation in meaningful learning activities, instead of ICT integration being adopted as an objective in itself (Albion, Tondeur, Forkosh-Baruch, \& Peeraer, 2015; Kozma, 2003).

Likewise, there is a special interest on the part of the technology sector in developing products and services that help to continuously improve ICT, from the perspective of its implementation and integration within the educational world, as evidenced by educational projects using Telefónica Foundation ICT, examples of which are the projects "Mobile Learning","Interactive Encyclopedia" and "Promoting our cultural roots using ICT".

As suggested in the report "Students, computers and learning: making the connection" (OECD, 2015), schools still need to make use of the potential of technology in the classroom

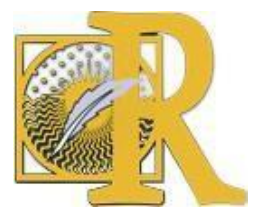


in order to address the digital divide, and to give each student the skills they need in today's connected world, according to the first OECD PISA evaluation of digital skills. Following this line of thought, this research aims to evaluate the impact of the use of ICT on mathematics performance in high school students considering not only the use of ICT, but also the process and background variables that influence ICT use, both by the student and at school level (Vázquez-Cano, 2012; 2013, 2016).

For this, linear hierarchical modeling analysis was used (HLM) thus monitoring the characteristics of the students and the school. Since little is known about the factors that link new technologies to school performance in general, the work detailed below is intended to provide new information on the relationship observed between factors related to ICT use and mathematics performance in students' learning processes, according to the statistics supplied by the OECD program, PISA 2009.

\section{Technology and academic performance.}

Information and Communication Technology (ICT) includes computers, the Internet and electronic systems such as sound equipment, televisions and projectors, among others, and is widely used in today's education field. School is an important environment in which students participate in a wide range of computer-based activities, while the home serves as a complementary site, since computer activities are more limited there (Kent \& Facer, 2004). ICT is increasingly applied successfully to teaching, learning and evaluation. In addition, learning is a continual, lifelong process, during which students alter their perspectives through seeking knowledge, which is different from more traditional approaches. As time goes by, it will be necessary to wait for and be willing to look for new sources of knowledge (Weert, Tatnall, \& International Federation for Information Processing, 2005). Therefore digital competence will be an essential requirement for these students in the coming years.

ICT tends to expand access to education, as through ICT, learning can occur at any time and in any place. Online course materials, for example, can be accessed 24 hours a day, seven days a week. Telematic classrooms allow both the student and the teacher to simultaneously interact, easily and conveniently. Now centred on ICT, learning and teaching no longer depend exclusively on printed materials. An abundance of resources can be found on the internet, and knowledge can be acquired through video clips, audio recordings, visual presentation of learning sources and so on. Current research has indicated that ICT helps transform a teaching environment into a learner-centered environment (Sánchez \& Alemán, 2011). Since students are actively involved in the learning process in ICT classrooms, this allows them to make decisions and plans. (Lu, Hou, \& Huang, 2010). Therefore ICT provides both students and teachers with more educational opportunities and possibilities.

Likewise, ICT develops a new understanding within students of their different areas of learning (Chai, Koh, Tsai, \& others, 2010). ICT provides more creative solutions to different types of learning-related issues. For example, during a literature class, electronic books are commonly used when a text is read aloud. Students can easily access all types of texts, from basic to advanced level, through computers, laptops or digital tablets. More specifically, these e-books may arrive pre-loaded with reading applications, which offer a read-aloud interface, relevant vocabulary-building activities, games related to reading skills and 
vocabulary acquisition and much more. Therefore, ICT incorporates specifically designed applications, which provide innovative ways to satisfy a variety of learning needs.

From a constructivist learning perspective, ICT helps students focus on higher-level concepts, rather than less meaningful tasks(Levin \& Wadmany, 2006). A recent study has shown that there are statistically significant correlations between learning via ICT and the acquisition of critical thinking skills (McMahon, 2009). Likewise, the same study has suggested that a greater exposure to ICT-based learning environments can foster students' critical thinking skills. Consequently, it strongly recommends that schools integrate technology into all areas of learning and within all levels of learning. When this is done, students are able to apply technology in order to achieve higher levels of understanding within specific learning contexts.

Although the advantages of using ICT in the classroom have been demonstrated in previous research, there are barriers or challenges associated with its use. It has been shown that students' mobility, any special needs that they may possess, along with students' anxiety about standardised test results are the main challenges associated with ICT use (Frederick, Schweizer, \& Lowe, 2006). These challenges can be solved by providing truly useful learning activities based on groups and problems, plus adequate learning support (Whelan, 2008). Further barriers have also been identified from the students' perspective, including: basic technical skills that reduce access to ICT in the classroom, an insufficient number of academic advisors and a lack of timely feedback from teachers, plus reduced interaction with peers and teachers. Therefore the author recommends the following strategies to facilitate the learning process: more initial guidance and better training for students, greater emphasis on the importance of teacher access and more effective administration, and the expansion of podcasting and online conference tools. In general, capacity building, curricular development, infrastructure, policies and government support are required to minimise student barriers and increase the effectiveness of ICT use in the classroom. In addition, students are advised to acquire specific technical skills to enable ICT-based learning (Sánchez \& Alemán, 2011).

A type of technology-based learning in which the learner and the teacher do not share the same space but in which both parties can decide their own learning or teaching time is called e-learning. Through this way of teaching, the student and the teacher can manage their time independently. There are authors of field-specific literature who have highlighted the benefits of this educational strategy, but nevertheless there are others who believe there to be few benefits. Controversy surrounding the positive influence of technology, specifically referring to "multimedia" technology and with an emphasis on concern for students' learning, has existed since before the 1980s.

Previously, there was an initial wave of social excitement in the early twentieth century, during which it seemed like the emergence of new technological advances in mass media would produce a change in methodology and, therefore, improvements in the educational system, especially in relation to school performance. This was not the case, and it has been demonstrated on many occasions that the instruction of the teacher is the only influence upon learning, rather than the means used to teach. (Clark, 1983). However, not all researchers agree.

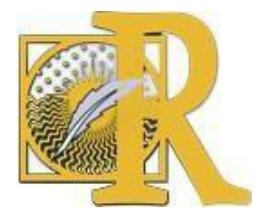


The methodology used in learning processes requires devices that depend on the teaching strategy used at a given time. These instruments have evolved and new ones have appeared. Our information-based society tests our individual capacity to take advantage of the power of emerging technologies, and this depends on the creativity of designers, their ability to exploit the potential of mass media and our understanding of the relationship between these abilities and our learning (Kozma, 1991). Researchers have already undertaken studies (Mayer, 2003; Li \& Ma, 2010), which show the positive effects of technology upon academic achievement. A more current approach suggests that technology-based learning is enabled by the methodology with which it is used, since this stimulates knowledge acquisition and memory, rather than learning being enabled by the mere use of technology within teaching. (Mayer, 2010).

The greatest challenge is observed in the form of educational involvement. Which technology-based resources and uses of technology have a positive impact and which do not? How frequently should technology be used and from which point onwards does the use of technology become counterproductive? Recent research points to the drawbacks of high frequency technology use, and it has been discovered that the amount of technology used is, when considered alone, not important to learning outcomes(Lei \& Zhao, 2007). On the other hand, two out of every three European students use the internet to obtain information when completing their schoolwork. Despite the positive attitudes mentioned above, a higher level of negative attitudes was noted among students from countries with a low level of access to ICT (Oana \& Carmen, 2014). According to the above, it can be concluded that emphasis should also be placed on the quality of technology use and not only on amassing technological resources.

Often an innovative educational solution involves taking into account a variety of learning environments. For example combined learning methodology (blended learning) allows the student to study at their own pace. Within this method, learning may include text readings, projects related to class activities, online assignments completed before the final class task and a classroom session followed by discussions in the virtual classroom as well as via online forums. All this is managed by the student based on three main considerations: the objective of their studies, the prior knowledge of the student and the context in which they will develop and implement their learning (R. C. Clark \& Mayer, 2016).

The development of ICT use in the education field has attracted the interest of education researchers from different countries and as a result there have been many research studies focusing on the relationship between ICT and academic achievement. In particular, a large number of them have used national or international evaluation data, such as that of PISA, to explore this relationship and provide comparable data that enables countries to improve their education policies and their academic results.

Several studies have found that the availability and use of technology has positive effects on student performance, finding that digital skills are acquired primarily through technologybased learning at home, and less so through direct instruction in the classroom (Lauman, 2000; Braak \& Kavadias, 2005; Kuhlemeier \& Hemker, 2007; Zhong, 2011). Other studies highlight improvements in the results of ICT-based education within school when home computers are used as a reference to promote exploratory, initial and experimental learning with ICT in the classroom (Mumtaz, 2000). More recently, research carried out on Turkish 
students, using the PISA 2009 data set, showed that students' ICT use outside of school hours had a greater impact on their mathematical and scientific achievements than their use of technology at school (Delen \& Bulut, 2011). On the contrary, other investigations suggest that this has only a marginal influence on the prediction of their academic achievements. This conclusion is corroborated by the results of the 2000 and 2003 PISA tests, which show a minor impact on students' mathematics performance (Woessmann \& Fuchs, 2004; Wittwer \& Senkbeil, 2008).

This diversity of results could be due to the fact that the relationship between ICT use and school performance is influenced by other background variables, along with variables related to the teaching process. On this subject, there have been studies based on PISA in which ICT use explained a significant portion of the general variance in mathematical performance, although the ICT-based teaching of the school was more important than the ICT competence possessed by students. Therefore, that is to say that support at school level is essential to increasing the impact of ICT-based learning (Song \& Kang, 2012).

Amongst background variables is the limited capacity of schools to incorporate and absorb new technology, and consequently changes in teaching-learning methods, in general, tend to be implemented moderately carefully. On the basis of these considerations, the following hypothesis is established:

Hypothesis: the academic performance of a specific school subject will improve if ICT is used logically and effectively and is also useful and compatible with teaching the topic being studied, at the right time and in the correct context and without elements that distort the class content.

Five considerations were used to gather information on the use of ICT for school-related tasks in the PISA 2009 study, the survey of the Program for the International Evaluation of OECD Students, which is held every three years. They are as follows: using the internet to support school work (for example, the preparation of an essay or presentation), using emails to communicate with other students in order to do school work, using emails to communicate with teachers and to submit homework or other school work, downloading, uploading or searching for content from the school website (for example schedules or course materials) and checking the school website in order to view important notifications (for example, the absence of teachers).

In particular, Weinstein et al argue that the educational value of ICT increases by encouraging the establishment of connections, achieved by teaching strategies which create a personal meaning for the learner. This is one reason why new information is important for the student to remember long term, therefore it can be said that the student learns things more easily if they have personal value, that is to say what makes sense for them and can be linked to what has already been learned. (Weinstein, Ridley, Dahl, \& Weber, 1989).

When a lot of information is made available to students, the ability to know how to learn becomes highly important. Knowing how to obtain and make judgements about valuable information plays an important role when learning, and satisfies the needs of students with different skills, motivations and interests. Therefore, ICT, when used effectively, can benefit repetitive learning, memorisation, stimulate mental connections, help students discover alternative methods of finding solutions, as well as stimulating creativity through lateral thinking strategies(De Bono, 1967). 
Given that information technology provides greater opportunities to create new learning experiences, in which students feel more involved in the teaching-learning process (Crawford, Gordon, Nicholas, \& Prosser, 1998) and although the tools of technology do not solve the understood existing cultural habits of students, they do help to generate academic understanding (Orton-Johnson, 2009). Some researchers have found the use of computers at home to be associated with better academic performance (Wittwer \& Senkbeil, 2008). When students have, for example, homework difficulties, they can rely on ICT for activities such as searching the internet for relevant information or communicating with teachers and classmates through email and chat platforms.

According to Jonassen, it can be argued that students improve their competence level because they use the computer at home as a cognitive tool that immerses them in problem solving activities, in a self-determined manner, which in turn strengthens their academic achievements(Jonassen, 2000). This is precisely the approach that has been chosen within this research as a definition of effective ICT use.

One of the most consistent findings related to ICT use is the impact on intermediate variables such as student motivation and concentration. However, (Passey, Rogers, Machell, McHugh, \& Allaway, 2004) it has also been observed that the mere presence of the computer is not enough to increase motivation. This is especially the case for students who use ICT more at home than they do at school. For the use of ICT to be motivational in school, it must be accompanied by assignments and appropriate guidance from the teacher. By increasing motivation, ICT has an impact on the quality of students' work, but in order for these achievements to be fully realised, ICT must be used to support subject learning, and related issues such as participation and presentation of the task must also be addressed.

\section{Methodology.}

The interest of the present investigation lies in discovering the degree of quantitative association between some of the variables in our environment, which are involved in the teaching and learning process. To this end, the mathematical regression model has been chosen since it allows us to apply the requirements of the scientific method.

Frequently, in social science investigations, there is the issue of discovering the relationship between variables associated with individuals, whilst also taking into account the fact that that variables associated with the groups to which these individuals belong may also intervene. This leads to the suggestion that the data that has been measured can be modelled as a hierarchical-level structure, in which individuals are considered in a subset included in the set of groups.

Multilevel modeling is used in statistical analysis when the data associated with the individuals under study is organised not only on a single level, but in a way that could be considered hierarchical. It is understood, therefore, that in some cases data is organised so that the observations become grouped into different cluster levels, that is to say that the individuals in the lower level form groups within the upper level. Such data appears within various fields, for example in educational research in which students are grouped within schools, in family studies in which children are grouped within families, in medical research in which patients are grouped by assignment to specialists for medical consultations and in geopolitical research, in which respondents are selected from certain cities within their

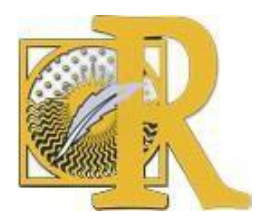


autonomous communities. Clustered data may also emerge as a result of the specific way an investigation is designed. For example, in large-scale survey research, data collection is usually organised into a multi-stage sampling design that results in pooled or stratified data. Another example is longitudinal design, in which data comes from a series of measurements repeated over a period of time, and is grouped into individual categories.

Taking education as an example, the processes that affect a student's school performance can operate on several scales simultaneously. It can be suggested that exam results are affected by individual variables (for example, each student's capacity and the number of hours of homework given), class variables (for example, the average academic ability of classmates and the ratio of students in the classroom), variables at school level (teacherstudent ratio and expenditure per student) and intrinsic factors associated with each student, classroom and school. Consequently, working at only one level is very likely to lead to a distorted representation of reality. Therefore, estimates of the relationship between the average level of academic performance in a school and the combined characteristics of the school (the so-called ecological means of media analysis) can give very misleading results if the individual characteristics of the students are ignored. Similarly, if a model is only analysed at an individual level, the "contextual" effects of the classroom or school are not taken into account. Being in a high-performing class can affect the performance of an individual student in addition to, or in interaction with, the student's own characteristics.

This was a field study in which mixed research methods were used, including surveys, along with numerical measurements, which were processed using statistical tools (Sampieri, Collado, \& Lucio, 2014). Its data was obtained through the focus group carried out by the PISA 2009 program. PISA (Program of International Student Assessment) is managed by the Organization for Economic Cooperation and Development (OCDE). Academic performances were analysed through external evaluation, which was based on competency measurement. Competence is understood as the ability to apply the knowledge learned to real-life situations (OECD, 2010). The sample consists of 1448 students from 50 schools, collected by the PISA 2009 study, in the Autonomous Community of the Canary Islands. The study questionnaire used was the $\mathrm{HOMSCH}$ (IC05) in which students were asked to answer the following questions:

\section{HOMSCH (IC05) How often do you do the following at home?}

Q01. Browsing the internet for school work (for example, when preparing an essay or presentation).

Q02. Using emails to communicate with other students about school work.

Q03. Using emails to communicate with teachers and submit homework or other school work. 
Q04.

Downloading, uploading or searching for content from your school's website. (For example, timetables or course materials).

Q05. Checking the school website for announcements, for example teacher absences.

The set of possible answers which each student had to answer was the same for each question, and was as follows:

A01. Never or almost never.

A02. Once or twice a month.

A03. Once or twice a week.

A04. Every day or almost every day

Those cases in which there was no clear response from A01 to A04 are not part of the sample. Therefore, after discarding these cases, the sample consists of 1376 students instead of 1448.

The data was processed using the computer program Stata 12. Stata is a statistical software package created in 1985 by StataCorp. It is used mainly by academic and business institutions dedicated to research, particularly within economics, sociology, political science, biomedicine and epidemiology. Stata allows, among other functions, data management, statistical analysis, graphing and simulations.

The adopted analysis technique is based on the multilevel model. Multilevel regression models are statistical models of parameters that vary on more than one level. That is to say that individual observations (i) are grouped naturally in aggregate units (j). We can assume that a dependent variable may be determined by independent variables of the group or lower level (which we will call here individual level [i] or level one) or of the higher level (aggregate level [j] or level two). These models can be seen as elaborations of linear models (in particular, linear regression). Multilevel models are particularly appropriate for research designs in which data is organised for participants at more than one level (i.e. nested data). The student body of study, as part of the Spanish educational system, is part of a hierarchical organisation system, in which we can identify groups that can be classified within aggregate nesting levels, as follows: (level 1) the students enrolled in the educational centres and (level 2) the educational centres themselves. Multilevel mixed-effects models (mixed models) are characterised by both fixed effects and random effects(Hox, Moerbeek, \& van de Schoot, 2010). The fixed effects are comparable to the standard regression coefficients and are calculated directly. Random effects are not considered directly, but are

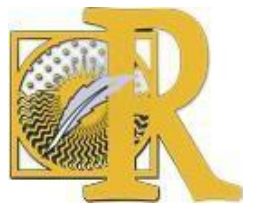


estimated in accordance with their estimated variances and covariances. As a consequence, the data collected within each level (random effect factors) is linked to the same specific random variable. This introduces dependence between each piece of data.

For the present investigation, the multilevel analysis applied to PISA 2009, which evaluated 15 year old students, is used as point of reference, as it takes into account the grouping of data in more than one category and estimates averages grouped by levels, resulting in the following model:

MEDIAMAT $_{i}=\frac{\left(\text { PV1MATH }_{i}+\text { PV2MATH }_{i}+\text { PV3MATH }_{i}+\text { PV4MATH }_{i}+\text { PVSMATH }_{i}\right)}{5}$

Where the subscript i refers to each case (student analysed) in particular and the subscript $j$ refers to each school.

$$
\begin{aligned}
\operatorname{MEDAMAT}_{i j}= & \beta_{0}+\beta_{1} I C 05 Q 01_{i j}+\beta_{2} I C 05 Q 02_{i j}+\beta_{3} I C 05 Q 03_{i j}+u_{0 j}+u_{1 j} I C 05 Q 01_{i j} \\
& +u_{2 j} I C 05 Q 02_{i j}+u_{3 j} I C 05 Q 03_{i j}+e_{i j}
\end{aligned}
$$

The research was complemented by a study of mathematics performance, exhibiting its gradient for each school. This allows us to know the trajectory that school performance takes, as the use of ICT becomes more frequent, and also indicates the degree of variation in performance trajectories.

\section{Results.}

From the data obtained for this model (Table 1), we can calculate the intraclass correlation coefficient (ICC) which indicates how much of the total variation in mathematics performance can be attributed to the differences between school management. The result indicates that approximately $27.54 \%$ of the variation in students' mathematics performance is explained by the differences between the schools in our study, leaving approximately $72.46 \%$ of variation in mathematics performance to the work of students within school and at home. The fact that a large proportion of variation in mathematics performance may be due to the students or the school environment itself highlights the importance of using methodology that takes into account the hierarchical structure of the data. 
Table 1:

Multile vel models for MEANMAT

\begin{tabular}{|c|c|c|c|c|}
\hline Model & M0: onlyintercept & $\begin{array}{l}\text { MI: + IC05Q0I } \\
\text { fixed gradients }\end{array}$ & $\begin{array}{l}\text { M2: + IC05Q01 } \\
\text { random gradient }\end{array}$ & $\begin{array}{c}\text { M3: + IC05Q0I } \\
\text { IC05Q02 IC05Q03 } \\
\text { random gradient }\end{array}$ \\
\hline \multicolumn{5}{|l|}{ Fixed effect } \\
\hline Predictor & Co efficiertt (EE) & Co efficiert (EE) & Co efficient (EE) & Co efficiert (EE) \\
\hline Intercept & $439.70(5.24)$ & $431.19(6.90)$ & $431.71(7.21)^{*}$ & $449.33(7.61)$ \\
\hline IC05Q01 & & $3.52(1.87)$ & $3.32(2.15)^{*}$ & $9.47(2,37)$ \\
\hline IC05Q02 & & & & $-9.03(2.31)$ \\
\hline IC05Q03 & & & & $-6.78(2.82)$ \\
\hline \multicolumn{5}{|l|}{ Random effect } \\
\hline \multicolumn{5}{|l|}{ Wariance level 1} \\
\hline$\sigma_{e}^{2}$ & 4642.00 & 4631.54 & $4575.87^{*}$ & 4291.30 \\
\hline \multicolumn{5}{|c|}{ Random effect level 2} \\
\hline$\sigma_{\mathrm{u} 0^{2}}$ & 1198.83 & 1184.24 & $1399.11^{*}$ & 1346.65 \\
\hline$\sigma_{\mathrm{u} 1^{2}}$ & & & $55.86^{*}$ & 62.70 \\
\hline$\sigma_{\mathrm{u} 2^{2}}$ & & & & 88.87 \\
\hline$\sigma_{u 3^{2}}$ & & & & 132.63 \\
\hline $\mathrm{AIC}$ & 15628.57 & 15627.03 & $15624.60^{*}$ & 15571.52 \\
\hline $\mathrm{BIC}$ & 15633.8 & 15637.49 & $15635.05^{*}$ & 15592.43 \\
\hline ICC & $20.53 \%$ & $20.36 \%$ & $24.13 \%$ & $27.54 \%$ \\
\hline Deviation & 15626.57 & 15623.03 & $15620.60^{*}$ & 15563.52 \\
\hline
\end{tabular}

*Data with p-vatue sigrificarre $>0.05$

From Table 1 it can also be deduced that for IC05Q01, IC05Q02 and IC05Q03 it is not only the relation between each variable and mathematics performance that is statistically significant. It is also noted that the relationship between IC05Q01 and mathematics performance, IC05Q02 and mathematics performance and IC05Q03 and mathematics performance (MEDIAMAT) also varies between schools. It was determined that the variable gradients were statistically significant for two reasons, firstly due to the $p$ values of the estimated components of variance, as well as the overall improvement in the goodness of fit of the model, when the random gradients were added. 


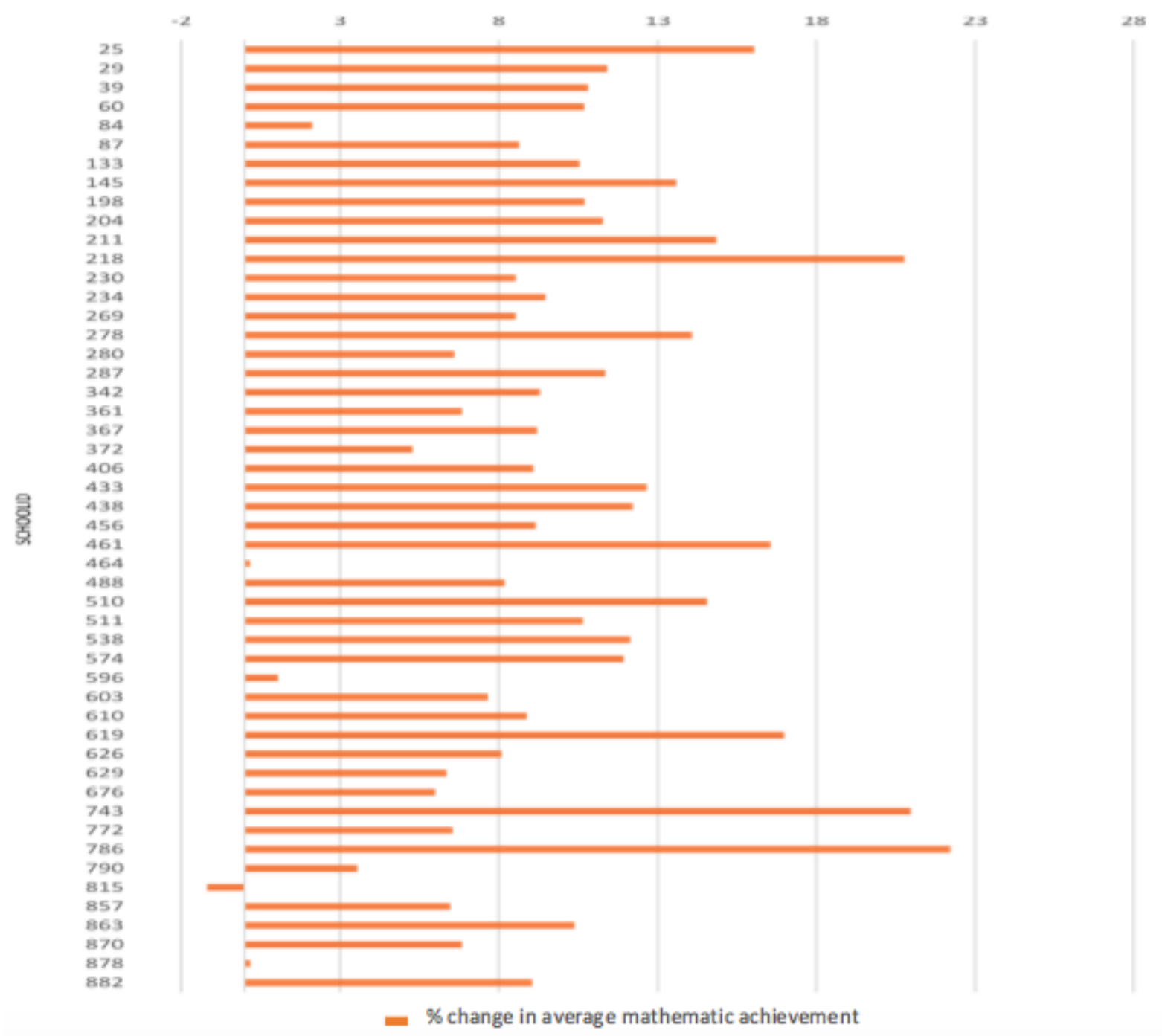

Figure 1. Mathematic performance behaviour per school

Figure 1 shows the performance of students using ICT versus those who do not use it (gradient), analysed school-by-school. The statistics for mathematics performance per school behaved similarly within the entire sample. There was only one school in which this tendency was the opposite. In general, mathematics performance per school clearly improves as ICT use increases. 


\section{Conclusions.}

In this research, mixed analysis was carried out to rigorously examine the exclusive impacts of the use of ICT on mathematics performance. This study examined the effects by identifying variance in mathematics performance explained by ICT use.

The variance explained by the difference in the way centres were managed in terms of ICT, considering only mathematics performance, was $27.54 \%$ for 15 year old students in the Autonomous Region of the Canary Islands. This places the focus on the students' ability to learn how to learn effectively, since improving attitudes towards autonomous learning would improve academic performance.

The results showed that using ICT in order to email other students about school work and using emails to communicate with teachers, along with the submission of homework or other school work, had a negative impact on performance. It follows that the use of excessive emailing, chat rooms and blogs can decrease mathematics performance when used inefficiently, and therefore this technology should be used with caution within education. However, a positive trend was observed when students used internet search tools in order to do school work. These considerations correspond to the conclusions made by other studies (Song \& Kang, 2012; Zhang, 2016).

A second form of analysis, namely that of statistical gradients, confirmed the same behaviour for practically all schools. In other words, the use of ICT improved academic performance in mathematics as students used ICT more frequently, seen school by school. Thus, the analysis carried out suggests that factors related to ICT use, derived from the PISA 2009 survey in the Autonomous Region of the Canary Islands, help to predict competence levels in academic mathematics performance. Together, these results provide empirical support for the initial hypothesis of this research.

The techniques of multilevel analysis and gradient study have been shown as valid, adequate and good quality techniques for studies conducted in schools, especially due to the set of contributions, both substantive and technical, provided by the former type of analysis (Torrecilla, 2012). These techniques helped to demonstrate that the use of ICT has its own effect on student performance in school. From the point of view of digital competency, the skills developed by students have a significant impact on school achievement in terms of information processing. That is to say that students need to develop a greater cognitive capacity to analyse and process information instead of an ability to just collect and communicate information. Additionally, it was found that confidence in internetbased tasks was beneficial in mathematics.

This implies that support for ICT in education should include assistance with equipment and facilities access, training and support for teachers, capacity building, educational content, distance education, digital literacy, policy development, monitoring and evaluation(CortinaPérez, Gallardo-Vigil, Jiménez-Jiménez, \& Trujillo-Torres, 2014; Sayans-Jiménez, VázquezCano, \& Bernal-Bravo, 2018).

The results of our research contrast with the results of other studies, which have found that student computer use at home only played a marginal role in predicting their academic achievements. (Clark, 1994; Wittwer \& Senkbeil, 2008). However, other authors have demonstrated that a significant proportion of variance in school performance can be explained by variables related to computer use. (Kozma, 1991; Papanastasiou, Zembylas, \&

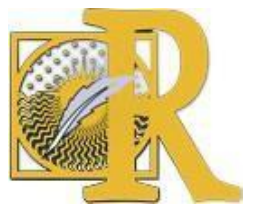


Vrasidas, 2003). One of the reasons for this discrepancy lies in the fact that, from an instructional point of view, if different learning outcomes are to be observed, different learning conditions are required. The incorporation of ICT into education requires a rethinking of the teaching-learning process, because if students repeat the learning processes used prior to the incorporation of ICT, nothing can be expected to change and past academic performance will be repeated (Gagné \& Gagné, 1985; Jonassen, 2000).

Although this research has fulfilled its objectives, there were some unavoidable limitations. On the one hand, given that the scope of this research was limited, for the purpose of the study, to the scope of the Canary Islands and to the levels of the students and their school centres, it would be desirable in future research to contrast and further widen results using larger groups, wherein the study would need to involve more participants in more levels. On this basis, the next step would be to build a stronger global evidence base.

On the other hand, the study was carried out using only the questions posed in the $\mathrm{HOMSCH}$ questionnaire (IC05) from the PISA 2009 study. Therefore, to obtain additional and more detailed conclusions, the questionnaire should have incorporated more devices of different uses, different learning procedures and the variety of different technology that students use at home.

Finally, it seems obvious that it is necessary to deepen investigations in order to obtain a better knowledge of the use that students make of new technology. Likewise, it is necessary to strengthen both initial and long-term teacher training, in order to encourage the development of skills-based and situation-based ICT competency (López-Gil \& Bernal Bravo, 2018; Rodríguez-Gutiérrez, Muñoz-Fernández, \& Luque-Vílchez, 2018). Common sense leads us to think that within the information-based society in which we all participate, we do not sufficiently take advantage of the enormous potential of ICT. Technology has the virtue of being a resource which is flexible and adaptable to any learning situation. We can make use of the technology that the industry has already developed and, if a new form of technology is needed in order to help students, we propose that it is investigated. ICT still has an enormous unexplored potential. It seems crucial to deepen the way in which students use electronic resources effectively at home and instead of investigating how frequently the resource is used, or whether it is used at all, it would be worthwhile to inquire about how the resource can be used most efficiently. This makes the investigation of computer use at home and its effects on school performance a more laborious process. However, it also reduces the possibility of biased conclusions about the benefits, in relation to their academic achievement, of students using ICT at home.

\section{References}

- Albion, P. R., Tondeur, J., Forkosh-Baruch, A., \& Peeraer, J. (2015). Teachers' professional development for ICT integration: Towards a reciprocal relationship between research and practice. Education and Information Technologies, 20(4), 655-673. https://doi.org/10.1007/s10639-015-9401-9

- Alenezi, A. M. (2018). E-assessment through Tablets and Smart phones: An attitudinal assessment of teachers. IJERI: International Journal of Educational Research and Innovation, (11), 1-17. Recuperado de: https://www.upo.es/revistas/index.php/lJERl/article/view/3292

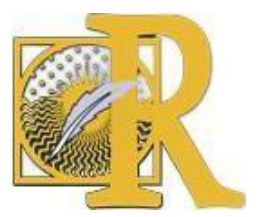


- Aristovnik, A. (2012). The impact of ICT on educational performance and its efficiency in selected EU and OECD countries: a non-parametric analysis. Available at SSRN 2187482. Recuperado de: http://papers.ssrn.com/sol3/papers.cfm?abstract id=2187482

- Aristovnik, A. (2014). Development of the Information Society and Its Impact on the Education Sector in the EU: Efficiency at the Regional (NUTS 2) Level. Turkish Online Journal of Educational Technology-TOJET, 13(2), 54-60.

- Baller, S., Dutta, S., \& Lanvin, B. (2016). The global information technology report 2016. En World Economic Forum, Geneva (pp. 1-307). Recuperado de: http://www.aciem.org/home/images/Prensa/Newsletter/PDF Notas Prensa Int Gen 07 Jul 2016.pdf

- Baris, M. F. (2015). Future of E-Learning: Perspective of European Teachers. Eurasia Journal of MathemaTIC, Science and Technology Education, 11(2), 421-429. https://doi.org/10.12973/eurasia.2015.1361a

- Belcher, J. W. (2001). Studio physics at mit. Šaltinis internete. Recuperado de: http://web. mit. edu/8.02 t/www/802TEAL3D/visualizations/resources/PhysicsNewsLetter. pdf

- Braak, J. V., \& Kavadias, D. (2005). The influence of social-demographic determinants on secondary school children's computer use, experience, beliefs and competence. Technology, Pedagogy and Education, 14(1), 43-59. https://doi.org/10.1080/14759390500200192

- Breslow, L. (2010). Wrestling with pedagogical change: the TEAL initiative at MIT. Change: The Magazine of Higher Learning, 42(5), 23-29.

- Chai, C. S., Koh, J. H. L., Tsai, C.-C., \& others. (2010). Facilitating preservice teachers' development of technological, pedagogical, and content knowledge (TPACK). Educational Technology \& Society, 13(4), 63-73.

- Cinganotto, L., Panzavolta, S., Garista, P., Guasti, L., \& Dourmashkin, P. (2016). TEAL as an innovative teaching model Insights from «Educational Avant-Garde» Movement in Italy. Journal of e-Learning and Knowledge Society, 12(2), 115-126.

- Clark, R. C., \& Mayer, R. E. (2016). E-learning and the science of instruction: proven guidelines for consumers and designers of multimedia learning (Fourth edition). Hoboken, New Jersey: Wiley.

- Clark, R. E. (1994). Media will never influence learning. Educational technology research and development, 42(2), 21-29.

- Cortina-Pérez, B., Gallardo-Vigil, M. Á., Jiménez-Jiménez, M. Á., \& Trujillo-Torres, J. M. (2014). Digital illiteracy: a challenge for 21st century teachers / El analfabetismo digital: un reto de los docentes del siglo XXI. Cultura Y Educación, 26(2), 231-264.

https://doi.org/10.1080/11356405.2014.935108

- Crawford, K., Gordon, S., Nicholas, J., \& Prosser, M. (1998). Qualitatively different experiences of learning mathemaTIC at university. Learning and Instruction, 8(5), 455468.

- De Bono, E. (1967). The use of lateral thinking. London: Jonathan Cape.

- Delen, E., \& Bulut, O. (2011). The relationship between students' exposure to technology and their achievement in science and math. TOJET: The Turkish Online Journal of Educational Technology, 10(3).

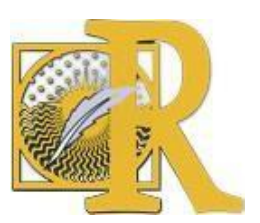


- Fombona Cadavieco, J., \& Vázquez-Cano, E. (2017). Posibilidades de utilización de la Geolocalización y Realidad Aumentada en el ámbito educativo. Educación XX1, 20(2), 319-342. https://doi.org/10.5944/educxx1.19046

- Frederick, G. R., Schweizer, H., \& Lowe, R. (2006). After the in-service course: Challenges of technology integration. Computers in the Schools, 23(1-2), 73-84.

- Fry, K. (2001). E-learning markets and providers: some issues and prospects. Education + Training, 43(4/5), 233-239.

- Gagné, R. M., \& Gagné, R. M. (1985). The conditions of learning and theory of instruction (4th ed). New York: Holt, Rinehart and Winston.

- Hox, J. J., Moerbeek, M., \& van de Schoot, R. (2010). Multilevel analysis: techniques and applications. Routledge.

- Jonassen, D. H. (2000). Toward a design theory of problem solving. Educational Technology Research and Development, 48(4), 63-85.

- Kent, N., \& Facer, K. (2004). Different worlds? A comparison of young people's home and school ICT use. Journal of computer assisted learning, 20(6), 440-455.

- Kozma, R. B. (1991). Learning with media. Review of educational research, 61(2), 179_ 211.

- Kozma, R. B. (2003). Global perspectives. Learning \& Leading with Technology, 31(2), 6.

- Kuhlemeier, H., \& Hemker, B. (2007). The impact of computer use at home on students' Internet skills. Computers \& Education, 49(2), 460-480. https://doi.org/10.1016/j.compedu.2005.10.004

- Lauman, D. J. (2000). Student Home Computer Use: A Review of the Literature. Journal of Research on Computing in Education, 33(2), 196-203. https://doi.org/10.1080/08886504.2000.10782309

- Lei, J., \& Zhao, Y. (2007). Technology uses and student achievement: A longitudinal study. Computers \& Education, 284-296. https://doi.org/10.1016/j.compedu.2005.06.013

- Levin, T., \& Wadmany, R. (2006). Teachers' beliefs and practices in technology-based classrooms: A developmental view. Journal of Research on Technology in Education, 39(2), 157-181.

- Li, Q., \& Ma, X. (2010). A Meta-analysis of the Effects of Computer Technology on School Students' MathemaTIC Learning. Educational Psychology Review, 22(3), 215-243. https://doi.org/10.1007/s10648-010-9125-8

- Liu, H. C., \& Yen, J. R. (2014). Effects of Distance Learning on Learning Effectiveness. EURASIA Journal of MathemaTIC, Science \& Technology Education, 10(6), 575-580. https://doi.org/10.12973/eurasia.2014.1218a

- López-Gil, M., \& Bernal Bravo, C. (2018). El perfil del profesorado en la Sociedad Red: reflexiones sobre la competencia digital de los y las estudiantes en Educación de la Universidad de Cádiz. IJERI: International Journal of Educational Research and Innovation, 11, 83-100. Recuperado de: https://www.upo.es/revistas/index.php/lJERl/article/view/3265

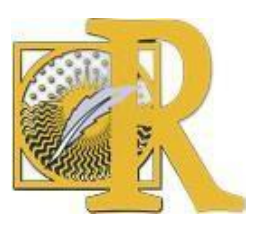


- López-Pérez, M. V., Pérez-López, M. C., \& Rodríguez-Ariza, L. (2011). Blended learning in higher education: Students' perceptions and their relation to outcomes. Computers \& Education, 56(3), 818-826. https://doi.org/10.1016/i.compedu.2010.10.023

- Lu, Z., Hou, L., \& Huang, X. (2010). A research on a student-centred teaching model in an ICT-based English audio-video speaking class. International Journal of Education and Development using Information and Communication Technology, 6(3), 101.

- Mayer, R. E. (2003). The promise of multimedia learning: using the same instructional design methods across different media. Learning and Instruction, 13(2), 125-139. https://doi.org/10.1016/S0959-4752(02)00016-6

- Mayer, R. E. (2010). Learning with technology. En H. Dumont, D. Istance, F. Benavides, \& OECD (Eds.), The nature of learning: using research to inspire practice (pp. 179-198). Paris: OECD.

- McMahon, G. (2009). Critical thinking and ICT integration in a Western Australian secondary school. Educational Technology \& Society, 12(4), 269-281.

- Moore, M. G., \& Kearsley, G. (2012). Distance education: a systems view of online learning (3rd ed). Belmont, CA: Wadsworth Cengage Learning.

- Mumtaz, S. (2000). Factors affecting teachers' use of information and communications technology: a review of the literature. Journal of Information Technology for Teacher Education, 9(3), 319-342. https://doi.org/10.1080/14759390000200096

- Oana, C., \& Carmen, C. (2014). What do PISA 2012 results tell us about European students' ICT access, ICT use and ICT attitudes? ADLRO. Recuperado de: https://doi.org/10.12753/2066-026X-14-064

- OECD. (2010). PISA 2009 Results: What Students Know and Can Do. OECD Publishing. Recuperado de: http://www.oecd-ilibrary.org/education/pisa-2009-results-what-studentsknow-and-can-do 9789264091450-en

- OECD (Ed.). (2015). Students, computers and learning: making the connection. Paris: OECD.

- Orton-Johnson, K. (2009). 'I've stuck to the path I'm afraid': exploring student non-use of blended learning. British Journal of Educational Technology, 40(5), 837-847. https://doi.org/10.1111/j.1467-8535.2008.00860.x

- Papanastasiou, E. C., Zembylas, M., \& Vrasidas, C. (2003). Can computer use hurt science achievement? The USA results from PISA. Journal of science education and technology, 12(3), 325-332.

- Passey, D., Rogers, C., Machell, J., McHugh, G., \& Allaway, D. (2004). The motivational effect of ICT on pupils. Department of Educational Research.

- Rodríguez-Gutiérrez, P., Muñoz-Fernández, G. A., \& Luque-Vílchez, M. (2018). Estudio exploratorio sobre el panorama actual de la formación inicial del profesorado de secundaria en España. IJERI: International Journal of Educational Research and Innovation, (11), 169-184. Recuperado de: https://www.upo.es/revistas/index.php/lJERI/article/view/2808

- Sayans-Jiménez, P., Vázquez-Cano, E., \& Bernal-Bravo, C. (2018). Influence of family wealth on student reading performance in PISA. Revista de Educación, 380, 129-155. doi: 10.4438/1988-592X-RE-2017-380-375.

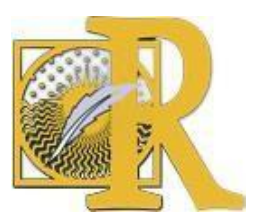


- Sampieri, R. H., Collado, C., \& Lucio, P. (2014). Metodología de la investigación. D.F: McGraw-Hill Education.

- Sánchez, J. J. C., \& Alemán, E. C. (2011). Teachers' opinion survey on the use of ICT tools to support attendance-based teaching. Computers \& Education, 56(3), 911-915.

- Sevillano, M. a L., \& Vázquez-Cano, E. (2015). The impact of digital mobile devices in Higher Education. Educational Technology \& Society, 18(1), 106-118.

- Simonson, M. R. (Ed.). (2012). Teaching and learning at a distance: foundations of distance education (5th ed). Boston: Allyn \& Bacon.

- Song, H.-D., \& Kang, T. (2012). Evaluating the Impacts of ICT Use: A Multi-Level Analysis with Hierarchical Linear Modeling. Turkish Online Journal of Educational TechnologyTOJET, 11(4), 132-140.

- Sulcic, V., \& Lesjak, D. (2009). E-learning and study effectiveness. The Journal of Computer Information Systems, 49(3), 40-47.

- Torrecilla, F. J. M. (2012). Los modelos multinivel como herramienta para la investigación educativa. Magis. Revista Internacional de Investigación en Educación, 1(1). Recuperado de: http://revistas.javeriana.edu.co/index.php/magis/article/view/3355

- Umek, L., Aristovnik, A., Tomazevic, N., \& Kerzic, D. (2015). Analysis of Selected Aspects of Students' Performance and Satisfaction in a Moodle-Based E-Learning System Environment. EURASIA Journal of MathemaTIC, Science \& Technology Education, 11(6), 1495-1505. https://doi.org/10.12973/eurasia.2015.1408a

- Vázquez-Cano, E. (2012). Mobile learning with Twitter to improve linguistic competence at Secondary Schools. The New Educational Review, 29(3), 134-147.

- Vázquez-Cano, E. (2013). The Videoarticle: New Reporting Format in Scientific Journals and its Integration in MOOCs. Comunicar, 41, 83-91. doi: http://dx.doi.org/10.3916/C412013-08

- Vázquez-Cano, E. (2014). Mobile Distance learning with Smartphones and Apps in Higher Education. Educational Sciences: Theory \& Practice, 14(4), 1-16. doi: 10.12738/est.2014.4.2012

- Vázquez-Cano, E. (2016). Dificultades del profesorado para planificar, coordinar y evaluar competencias clave. Un análisis desde la Inspección de Educación. Revista Complutense de Educación, 27(3), 1061-1083. doi: http://dx.doi.org/10.5209/rev RCED.2016.v27.n3.4740

- Weert, T. J. van, Tatnall, A., \& International Federation for Information Processing (Eds.). (2005). Information and communication technologies and real-life learning: new education for the knowledge society. New York: Springer.

- Weinstein, C. E., Ridley, D. S., Dahl, T., \& Weber, E. S. (1989). Helping students develop strategies for effective learning. Educational Leadership, 46(4), 17-19.

- Whelan, R. (2008). Use of ICT in education in the South Pacific: findings of the Pacific eLearning Observatory. Distance Education, 29(1), 53-70.

- Wittwer, J., \& Senkbeil, M. (2008). Is students' computer use at home related to their mathematical performance at school? Computers \& Education, 50(4), 1558-1571. https://doi.org/10.1016/j.compedu.2007.03.001

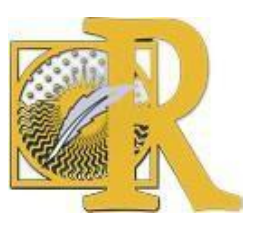


- Woessmann, L., \& Fuchs, T. (2004). Computers and student learning: Bivariate and multivariate evidence on the availability and use of computers at home and at school. Recuperado de: https://papers.ssrn.com/sol3/papers.cfm?abstract id=619101

- Zhang, D. (2016). How Does ICT Use Influence Students' Achievements in Math and Science Over Time? Evidence from PISA 2000 to 2012. EURASIA Journal of MathemaTIC, Science \& Technology Education, 12(10). https://doi.org/10.12973/eurasia.2016.1297a

- Zhong, Z.-J. (2011). From access to usage: The divide of self-reported digital skills among adolescents. Computers \& Education, 56(3), 736-746.

https://doi.org/10.1016/j.compedu.2010.10.016 